\title{
Fish Parasite Community of Three Lakes with Different Trophic Status in Mecklenburg-Western Pomerania, Germany
}

\author{
Jaydipbhai Suthar ${ }^{1}$ (1) $\cdot$ Patrick Unger ${ }^{1} \cdot$ Harry W. Palm ${ }^{1}$
}

Received: 21 April 2021 / Accepted: 23 August 2021 / Published online: 7 September 2021

(C) The Author(s) 2021

\begin{abstract}
Purpose The present study investigates the fish parasite fauna from Lake Tollense, Mecklenburg-Western Pomerania, Germany.

Methods A total of 117 perch (Perca fluviatilis), bream (Abramis brama) and roach (Rutilus rutilus) were sampled for parasites during 2018 and 2019 from Lake Tollense and compared with earlier data from Lake Malchin and Lake Hohen Sprenz in 2011 and 2014, respectively. Parasites were identified based on morphological and molecular characters.

Results A total of 32 parasite species were isolated from fishes of Lake Tollense, predominated by digeneans. Diplostomum baeri was found only in perch while D. spathacaeum was isolated from bream and roach. Parasite comparison of similar hosts between lakes revealed highly abundant Ichthyocotylurus spp. in perch and bream of Lake Malchin while Aspidogaster limacoides was most common in roach from Lake Tollense. Diversity indices of roach showed significant variation between localities. However, NMDS graph revealed separation of the three freshwater habitats based on the parasite fauna of perch, bream and roach.

Conclusion Based on the multivariate statistical analysis, the three natural inland water bodies could be distinguished based on the parasite communities of perch, bream and roach. The potential to utilise fish parasites as biological indicators in freshwater ecosystem is discussed.
\end{abstract}

Keywords Biological indicators $\cdot$ Parasite communities $\cdot$ Freshwater ecology $\cdot$ Germany

\section{Introduction}

Mecklenburg-Western Pomerania, situated in the North-east of Germany has more than 2000 lakes, most of which are natural and of ice age origin. With a coastline of approx. $2000 \mathrm{~km}$, over $33 \%$ of the land area is protected by law and has various unique ecosystems such as Lake Tollense, Malchin and Hohen Sprenz [1]. Lake Tollense is located in the eastern part of the Mecklenburg Lake District, southwest the city of Neubrandenburg, and is one of the largest water bodies in the state $\left(17.9 \mathrm{~km}^{2}\right)$ [2]. Lake Malchin is located in the North of the Mecklenburg Lake District with an area of 13.8 $\mathrm{km}^{2}$ while Lake Hohen Sprenz is situated south the city of Rostock with a surface area $2.25 \mathrm{~km}^{2}$ [2]. According to the

Jaydipbhai Suthar

jaydiphbai.suthar@uni-rostock.de

1 Aquaculture and Sea-Ranching, Faculty of Agricultural and Environmental Sciences, University of Rostock, Rostock, Germany
Ministry of Agriculture and the Environment of Germany (Data provided upon request; Seenprogramm MV), Lake Tollense is classified as mesotrophic 1, Lake Hohen Sprenz eutrophic 2 and Lake Malchin polytrophic 2.

The water bodies harbour diverse fish fauna [2], including the Eurasian perch, Perca fluviatilis (L.). This percid fish is adapted to different types of habitats ranging from small to large fresh and brackish water areas [3]. The species undergoes size-related ontogenic shifts in diet, e.g. larvae and juveniles are pelagic zooplankton feeders, switching to benthic invertebrates at intermediate sizes and finally, large sized perch mainly prey on fish [4]. Common bream, Abramis brama (L.), and roach, Rutilus rutilus (L.) are cyprinids and inhabit fresh- and brackish water [5]. Common bream is a filter-feeder and consumes zooplankton, insects, molluscs, plants and small fish [6, 7]. Roach is omnivorous, feeding on benthic invertebrates, zooplankton, molluscs, plant material and detritus [3, 8]. The two cyprinids are widely distributed in Europe [5] and in the lakes of northern Germany [2, 9]. 
The status of a freshwater habitat can be described by using parasitic organisms as biological indicators. For example, Valtonen et al. [10] linked parasite assemblages in roach and perch to the trophic status of four aquatic habitats in Finland-Lake Peurunka (oligotrophic), Lake Saravesi and Leppävesi (both eutrophic) and Lake Vatia (polluted). Moreover, a high-intensity of trichodinid ciliates was recorded on the longhorn sculpin, Myxocephalus octodecemspinosus (Mitchill, 1814) from a location exposed to crude oil pulp and paper mill effluents [11], and Palm and Dobberstein [12] suggested these ciliates as successful sentinels for eutrophication. Galli et al. [13] examined chub [Leuciscus cephalus L. now Squalius cephalus (L.)] from different freshwater localities in Italy and demonstrated that parasite distribution was influenced by the levels of pollution. They observed that the copepod Lamproglena pulchella (von Nordmann, 1832) and acanthocephalan Pomphorhynchus laevis (Zoega in Müller, 1776) were restricted to the unpolluted and slightly polluted habitats respectively, and digeneans Asymphylodora tincae (Modder, 1790) and Diplostomum spathaceum (Rudolphi, 1819) were absent in fish from severely polluted site. Palm [14] summarised the use of fish parasites as biological indicators, including the potential to indicate eutrophication and pollution.

Salzman et al. [15] attempted to use roach as a biological indicator for habitat size and pollution in anthropogenicinfluenced and man-made freshwater habitats in North Rhine-Westphalia, Western Germany. Parasitological investigations of fishes have been well documented in the German coastal waters $[16,17]$. However, despite numerous of lakes in this region, relatively few studies have been carried out on freshwater fish parasites in Mecklenburg-Western Pomerania. The most comprehensive study by Pikalov [18] listed 92 parasite species from freshwater fishes: 37 from perch, bream and roach. The purpose of the present study is an analysis of the parasite fauna of perch, bream and roach from three natural freshwater habitats (Lake Tollense, Lake Malchin and Lake Hohen Sprenz) of ice age origin in Mecklenburg-Western Pomerania. The current study was a detailed survey of fish parasites of Lake Tollense. Additionally, data from the other two lakes (by Pikalov) were incorporated to investigate the link between the conditions of the habitat (trophic status) and parasite diversity. The parasite communities are used as biological indicators with respect to the known characteristics of the lakes.

\section{Materials and Methods}

\section{Sample Site and Collection}

In total, 117 specimens of wild freshwater fishes belonging to perch, $P$. fluviatilis $(n=40)$, bream, A. brama $(n=30)$ and roach, $R$. rutilus ( $n=47)$ were sampled from Lake Tollense, $17.9 \mathrm{~km}^{2}$, maximum depth $31.3 \mathrm{~m}$ (mean $17.8 \mathrm{~m}$ ) [2], during 2018-2019. Host fishes (perch $=35$, bream $=35$ and roach $=35$ ) were collected by Pikalov [18] from Lake Malchin, $13.8 \mathrm{~km}^{2}$, maximum depth $10.0 \mathrm{~m}$ (mean 2.5), in 2011, and Lake Hohen Sprenz, $2.25 \mathrm{~km}^{2}$, maximum depth $17.3 \mathrm{~m}$ (mean 7.0) [2] (roach, $n=35$ ), also Mecklenburg-Western Pomerania, northern Germany. In 2014, with the original data set analysed and compared with the new samplings. All fishes were captured by local fishermen using fish traps and gillnet. The fishes were stored separately in labelled plastic bags and kept on ice during transport to the laboratory. They were deep frozen $\left(-18^{\circ} \mathrm{C}\right)$ on arrival at University of Rostock for subsequent parasitological investigation.

\section{Host Examination and Parasite Collection}

In the laboratory, fishes were defrosted at room temperature, measured (total and standard length), internal organs include weight of (total weight, gutted weight, internal organs such as liver, gonads, full stomach and empty stomach), and their sex was determined. Initially, according to the standard procedure of Palm and Bray [19], the external parts of the fishes (e.g. skin, eyes, gills, opercula, fins, buccal and mouth cavity) were studied for ectoparasites. Then, the body cavity was opened and rinsed with saline solution to detect parasites that inhabits the cavities and those attached to the mesenteries or other internal organs. Internal organs such as eyes, heart, liver, stomach, pyloric caeca, intestine, spleen, kidney, swim bladder, gall bladder and gonads were removed, transferred to a separate Petri-dish, washed in 0.9\% saline solution and examined for endoparasites. The examination was carried out under the stereomicroscope (Zeiss Stemi 305). Isolated parasites were placed in small glasses containing $0.9 \%$ saline solution, cleaned and fixed in ethanol (70\% and 99\%) for further morphological and molecular identification, respectively.

\section{Parasite Morphological and Molecular Analyses}

Parasite specimens preserved in $70 \%$ ethanol were isolated and permanent mounts prepared following standard staining procedures for each taxon $[18,20,21]$. The parasites were identified to the lowest taxa possible with the help of identification keys available in literature.

Selected Aspidogastrean and Digeneans fixed with $70 \%$ EtOH were stained with acetic carmine, whereas Acanthocephala and Nematoda were mounted on glycerine for light microscopic examination (BX53). Ectoparasites (Monogenea and Crustacea) were directly examined under light microscope after being isolated from fishes. The body, organs and taxonomically relevant characters were measured for Aspidogaster limacoides Diesing, 1834 
and Contracaecum rudolphii Hartwich, 1964. Monogeneans, Acanthocephalans, Nematoda and Crustacea were identified based on morphological features as provided by Pikalov [18].

For scanning electron microscopy (SEM), preserved specimens of A. limacoides were dehydrated in an ascending ethanol series and transferred to $100 \%$ acetone (twice for 10 min each), critical point dried (Emitech K850, Co. Quorum Technologies LTD, East Sussex), mounted on SEM-carrier with adhesive conductive carbon tape (Co. PLANO, Wetzlar), coated with gold under vacuum (EM SCD 004, Co. BALTEC, Balzers) and analysed using a field emission scanning electron microscope (FE-SEM, MERLIN $^{\circledR}$ VP Compact, Co. Zeiss, Oberkochen) at the Electron Microscopy Centre, University Medicine Rostock.

DNA was extracted from representative specimens (preserved in 99\% ethanol) following the standard protocol given in the DNeasy Blood \& Tissue kit (Qiagen, Germany).

Aspidogastrea: The ribosomal DNA (rDNA) region comprising the ITS-1, 5.8S, ITS-2 and flanking sequences $(=$ ITS +$)$ were amplified with the universal primers BD1 (5'-GTCGTAACAAGGTTTCCGTA-3') and BD2 (5'-TAT GCTTAA(G/A)TTCAGCGGGT-3'). Each PCR reaction was performed in a thermocycler (Biometra, Göttingen, Germany) under the following conditions: initial denaturation at $94{ }^{\circ} \mathrm{C}$ for $3 \mathrm{~min}$, followed by 40 cycles of $30 \mathrm{~s}$ denaturation at $94{ }^{\circ} \mathrm{C}, 30 \mathrm{~s}$ annealing at $54{ }^{\circ} \mathrm{C}$ and 2 min elongation at $72{ }^{\circ} \mathrm{C}$; and a final extension hold at $72{ }^{\circ} \mathrm{C}$ for $7 \mathrm{~min}$ [22].

Digenea: Complete ssrDNA rDNA was amplified using primers WormA (50-GCGAATGGCTCATTAAATCAG-30) and WormB (50-CTTGTTACGACTTTTACTTCC-30) using the following PCR cycling conditions: denature for $2 \mathrm{~min}$ at $94{ }^{\circ} \mathrm{C}$, followed by 40 cycles of $30 \mathrm{~s}$ at $94{ }^{\circ} \mathrm{C}, 30 \mathrm{~s}$ at $54{ }^{\circ} \mathrm{C}$, 2 min at $72{ }^{\circ} \mathrm{C}$; and 7 min extension at $72{ }^{\circ} \mathrm{C}$ [23].

Diplostomum spp.: Cox 1 region was amplified by using the diplostomid specific PCR primers: Plat-diplo COX1F (forward; 5'-CGTTTRAATTATACGGATCC-3') and Platdiplo COX1R (reverse; 5'-AGCATAGTAATMGCAGCA GC-3'). PCR reaction was performed in a thermocycler (Biometra, Gottingen, Germany) under the following conditions: initial denaturation at $95^{\circ} \mathrm{C}$ for 3 min followed by 35 cycles $\left(94{ }^{\circ} \mathrm{C}\right.$ for $30 \mathrm{~s}, 58{ }^{\circ} \mathrm{C}$ for $30 \mathrm{~s}$ and $72{ }^{\circ} \mathrm{C}$ for $2 \mathrm{~min}$ ), and a final extension step at $72{ }^{\circ} \mathrm{C}$ for 5 min [24].

Nematoda/Anisakidae: The region of rDNA comprising the ITS-1, 5.8S, ITS-2 and flanking sequences (=ITS+) was amplified using the primers Forward TK1 (5'-GGC-AAAAGT-CGT-AAC-AAG-GT-3') and Reverse NC2 (5'-TTAGTT-TCT-TTT-CCT-CCG-CT-3'). PCR cyclic started with an initial denaturation at $95^{\circ} \mathrm{C}$ for $1 \mathrm{~min}, 40$ cycles of $94{ }^{\circ} \mathrm{C}$ for $45 \mathrm{~s}$ (denaturation), $55^{\circ} \mathrm{C}$ for $45 \mathrm{~s}$ (annealing), $72{ }^{\circ} \mathrm{C}$ for $45 \mathrm{~s}$ (extension) and a final extension at $72{ }^{\circ} \mathrm{C}$ for $10 \mathrm{~min}$ [25].
The PCR products were purified as described in Qiagen DNeasy Blood \& Tissue Kit. For the sequencing, a mixture of purified PCR product and the above primers were used and sent to sequencing service (Seqlab, Göttingen).

Contiguous sequences were manually edited and assembled using BioEdit 7.2. The resulting sequences were subjected to nucleotide BLAST searches to find the highest matching sequences available in the Genbank (http://www. ncbi.nlm.nih.gov/blast).

\section{Parasitological and Diversity Parameters}

The ecological terms including prevalence $(\mathrm{P})$, mean intensity (MI), intensity (I) and mean abundance (MA) follow Bush et al. [26]. The prevalence of the different parasites was graded into core species $(>60 \%)$, secondary species $(40-60 \%)$, satellite species $(5-40 \%)$ and rare species $(<5 \%)$ after Holmes [27]. Analysis of component community parameters included species richness (number of parasite taxa), Shannon index of species diversity $(\mathrm{H})$, evenness index of Pielou (E), Berger-Parker Index (BP) and Simpson Index (S) were calculated $[18,28]$.

\section{Statistical Analysis}

Non-metric multidimensional scaling (NMDS) was performed with PRIMER 7 in order to visualise differences in the parasite fauna of roach from the three habitats. Prior to the proceeding of analysis, abundance data were square root transformed to reduce the impact of the dominant species on those with low abundance. Analysis of similarities (ANOSIM) was tested with Bray-Curtis similarity index to detect significant differences in the component community of roach in three lakes.

\section{Results}

\section{Parasite Identification}

The parasitological examination of three fish species, $P$. fluviatilis, A. brama and R. rutilus, from Lake Tollense revealed a total of 32 metazoan parasite species belonging to the Aspidogastrea (1), Digenea (14), Cestoda (5), Monogenea (4), Acanthocephala (2), Nematoda (4) and Crustacea (2). The parasitological terms such as prevalence, intensity, mean intensity, mean abundance and diversity indices together with the infection sites are presented in Table 1. The highest species richness and diversity was observed in P. fluviatilis and A. brama. Molecular identification (COX1 region) of Diplostomum spp. revealed the following two species: Diplostomum baeri Dubois, 1937 in perch (99\% similarity to GenBank accession number KM212030) and 
Table 1 Parasite fauna of three freshwater fishes from Lake Tollense, northern Germany

\begin{tabular}{|c|c|c|c|c|c|c|c|c|c|}
\hline \multirow{3}{*}{$\begin{array}{l}\text { Parasite species } \\
\mathrm{N}\end{array}$} & \multicolumn{3}{|c|}{ Perca fluviatilis } & \multirow{2}{*}{\multicolumn{3}{|c|}{$\frac{\text { Abramis brama }}{30}$}} & \multirow{2}{*}{\multicolumn{3}{|c|}{$\frac{\text { Rutilus rutilus }}{47}$}} \\
\hline & \multicolumn{3}{|l|}{40} & & & & & & \\
\hline & $\mathrm{P}(\%)$ & mI (I) & $\mathrm{mA}$ & $\mathrm{P}(\%)$ & $\mathrm{mI}(\mathrm{I})$ & $\mathrm{mA}$ & $\mathrm{P}(\%)$ & $\mathrm{mI}(\mathrm{I})$ & $\mathrm{mA}$ \\
\hline \multicolumn{10}{|l|}{ Aspidogastrea } \\
\hline Aspidogaster limacoides & - & - & - & 2.86 & $18.00(18)$ & 0.51 & 61.70 & $9.59(1-53)$ & 5.91 \\
\hline \multicolumn{10}{|l|}{ Digenea } \\
\hline Azygia lucii & 5.00 & $1.00(1)$ & 0.05 & - & - & - & - & - & - \\
\hline Bucephalus polymorphus & 15.00 & $4.67(1-12)$ & 0.70 & - & - & - & - & - & - \\
\hline Bunodera luciopercae & 100.00 & $173.83(6-540)$ & 173.83 & - & - & - & - & - & - \\
\hline Diplostomum baeri & 92.50 & $10.05(1-32)$ & 9.30 & - & - & - & - & - & - \\
\hline D. spathacaeum & - & - & - & 76.67 & $23.52(1-213)$ & 18.03 & 76.60 & $23.03(1-246)$ & 17.64 \\
\hline Gorgoderina lufengensis & - & - & - & 6.67 & $2.00(1-3)$ & 0.13 & - & - & - \\
\hline Ichthyocotylurus variegatus & 7.50 & $1.00(1)$ & 0.08 & - & - & - & - & - & - \\
\hline Lissorchis kritskyi & - & - & - & - & - & - & 2.12 & $5.00(5)$ & 0.11 \\
\hline Opecoelidae sp. & - & - & - & 56.67 & $41.65(1-210)$ & 23.60 & 31.91 & $7.27(1-47)$ & 2.32 \\
\hline Posthodiplostomum brevicaudatum & 15.00 & $9.17(1-42)$ & 1.38 & - & - & - & - & - & - \\
\hline Rhipidocotyle campanula & 5.00 & $0.50(1)$ & 0.03 & - & - & - & - & - & - \\
\hline Prosorhynchoides borealis & - & - & - & - & - & - & 2.12 & $1.00(1)$ & 0.02 \\
\hline Tylodelphys clavata & 95.00 & 38.18 (3-97) & 36.28 & 26.67 & $2.38(1-4)$ & 0.63 & 93.62 & $50.41(3-187)$ & 47.19 \\
\hline T. podicipina & 2.50 & $1.00(1)$ & 0.03 & - & - & - & - & - & - \\
\hline \multicolumn{10}{|l|}{ Cestoda } \\
\hline Bothriocephalus scorpii & 2.50 & $1.00(1)$ & 0.03 & - & - & - & - & - & - \\
\hline Caryophyllaeus laticeps & - & - & - & 40.00 & $16.33(1-59)$ & 6.53 & 4.26 & $1.00(1)$ & 0.04 \\
\hline Paradilepis scolecina & - & - & - & 53.33 & $21.06(1-94)$ & 11.23 & 17.02 & $5.88(1-23)$ & 1.00 \\
\hline Proteocephalus percae & 2.50 & $1.00(1)$ & 0.03 & - & - & - & - & - & - \\
\hline Triaenophorus nodulosus & 10.00 & $2.50(1-5)$ & 0.25 & - & - & - & - & - & - \\
\hline \multicolumn{10}{|l|}{ Monogenea } \\
\hline Ancyrocephalus percae & 2.50 & $1.00(1)$ & 0.03 & - & - & - & - & - & - \\
\hline Dactylogyrus sphyrna & - & - & - & 30.00 & $32.78(2-87)$ & 9.83 & 89.36 & $20.76(1-140)$ & 18.55 \\
\hline Diplozoan paradoxum & - & - & - & 46.67 & $3.57(1-7)$ & 1.67 & - & - & - \\
\hline Paradiplozoan homoin & - & - & - & - & - & - & 42.55 & $3.80(1-9)$ & 1.62 \\
\hline \multicolumn{10}{|l|}{ Acanthocephala } \\
\hline Acanthocephalus anguillae & - & - & - & 13.33 & $1.25(1-2)$ & 0.17 & - & - & - \\
\hline A. lucii & 7.50 & $3.00(1-7)$ & 0.23 & - & - & - & - & - & - \\
\hline \multicolumn{10}{|l|}{ Nematoda } \\
\hline Camallanus spp. & 100.00 & $27.00(3-91)$ & 27.00 & - & - & - & - & - & - \\
\hline Contracaecum rudolphii & - & - & - & 83.33 & $53.28(2-277)$ & 44.40 & 29.79 & $15.42(1-83)$ & 4.51 \\
\hline Philometra ovata & - & - & - & 6.67 & $1.50(1-2)$ & 0.10 & - & - & - \\
\hline P. rischta & - & - & - & - & - & - & 4.26 & $1.00(1)$ & 0.04 \\
\hline \multicolumn{10}{|l|}{ Crustacea } \\
\hline Argulus foliaceus & 2.50 & $1.00(1)$ & 0.03 & - & - & - & - & - & - \\
\hline Ergasilus sieboldi & - & - & - & 33.33 & $3.00(1-10)$ & 1.00 & 8.51 & $1.25(1-2)$ & 0.11 \\
\hline \multicolumn{10}{|l|}{ Ecological parameters } \\
\hline Richness & 16 & & & 13 & & & 13 & & \\
\hline Shannon Index $(\mathrm{H})$ & 0.96 & & & 1.75 & & & 1.50 & & \\
\hline Evenness (E) & 0.35 & & & 0.68 & & & 0.59 & & \\
\hline Simpson Index (S) & 1.92 & & & 4.45 & & & 3.33 & & \\
\hline Berger-Parker (BP) & 0.70 & & & 0.38 & & & 0.48 & & \\
\hline
\end{tabular}

I, intensity; MA, mean abundance; MI, mean intensity; N, number of examined fishes; $\mathrm{P}$, prevalence 
D. spathacaeum in bream and roach, with $100 \%$ and $99 \%$ similarity to GenBank accession number KR271459 and KR271429, respectively.

For anisakid nematodes, the ITS1-5.8S-ITS2 region of rDNA were generated from the isolated larval stages (L3) and analysis of BLAST showed $97 \%$ similarity to C. rudolphii, GenBank accession number MH778117. Sequences are deposited in Genbank under the accession numbers MW652700 (D. baeri, perch), MW652701 (D. spathaceum, bream), MW652702 (D. spathaceum, roach) and MW652707 (C. rudolphii, roach).

For Aspidogastrea, one species A. limacoides was identified based on morphology and molecular methods with highest prevalence in $R$. rutilus $(61.7 \%)$ and lowest in $A$. brama $(2.8 \%)$ [22].

Digenea was the most diverse taxon of which nine species parasitised $P$. fluviatilis, five occurred in $R$. rutilus while A. brama harboured four species. In P. fluviatilis, the most abundant digeneans were Bunodera luciopercae (Müller, 1776) $(\mathrm{P}=100.0 \% ; \mathrm{mI}=173.8)$, D. baeri $(\mathrm{P}=92.5$; $\mathrm{mI}=10.1)$ and Tylodelphys clavata (van Nordmann, 1832) $(\mathrm{P}=95.0 \% ; \mathrm{mI}=38.2)$. In A. brama, D. spathacaeum $(\mathrm{P}=76.7 \% ; \mathrm{mI}=23.2)$ was present in high numbers followed by Opecoelidae sp. $(\mathrm{P}=56.7 \% ; \mathrm{mI}=41.7)$. Metacercariae of Tylodelphys clavata (von Nordmann, 1832) $(\mathrm{P}=93.6 \%$; $\mathrm{mI}=50.4)$ and $D$. spathacaeum $(P=76.6 \% ; \mathrm{mI}=23)$ were highly abundant in $R$. rutilus (see Table 1 ).

For Cestoda, five species were found, of which Bothriocephalus scorpii (Müller, 1776), Proteocephalus percae (Müller, 1780) and Triaenophorus nodulosus (Pallas, 1781) occurred in P. fluviatilis. Additional two species (Caryophyllaeus laticeps (Pallas, 1781) and Paradilepis scolecina (Rudolphi, 1819)) were found in A. brama and $R$. rutilus, but with different prevalence and intensity. Around fifty percent of $A$. brama were infected with adult $C$. laticeps and cysts of $P$. scolecina. In $R$. rutilus, the prevalence of infection with $P$. scolecina and C. laticeps was $17.0 \%$ and $4.3 \%$, respectively.

Two adult Acanthocephala were found in the intestine of perch and bream, Acanthocephalus lucii (Müller, 1776) in perch and A. anguillae (Müller, 1780) in bream.

Three genera of Nematoda were found. Of these, Camallanus spp. was most abundant in perch and C. rudolphii was most abundant in bream. The genus Philometra consisted of two species, Philometra ovata (Zeder, 1803) reported in bream and Philometra rischta (Skrjabin, 1917) found in roach, but both with low prevalence (Table 1).

Four species of Monogenea were found: of these, Ancyrocephalus percae (Ergens, 1996) was present only in perch. Dactylogyrus sphyrna (Linstow, 1878) occurred in bream and roach with a prevalence of $30.0 \%$ and $89.4 \%$, respectively. The remaining species belonged to the family Diplozoidae, with Diplozoan paradoxum (von Nordmann, 1832) recorded from bream while Paradiplozoan homoion
(Bychowsky \& Nagibina, 1959) was reported from roach with almost similar prevalence, mean intensity and mean abundance (Table 1). Two different crustacean species, Argulus foliaceus (L., 1758) and Ergasilus sieboldi (Nordmann, 1832), were found on the gills. Perch was infected with a single specimen of $A$. foliaceus, while $E$. sieboldi was reported in bream and roach. Ergasilus sieboldi was more prevalent and abundant in bream $(\mathrm{P}=33.3 \% ; \mathrm{mI}=3.0)$ compared to roach $(\mathrm{P}=8.5 \% ; \mathrm{mI}=1.2)$.

\section{Diversity Parameters}

The highest species richness was recorded in perch (16), while bream and roach harboured 13 species each. The highest Shannon diversity was reported in bream (1.74) followed by roach (1.50) and perch (0.96). Accordingly, evenness was highest in bream (0.68) and lowest in perch (0.35). Simpson index and Berger-Parker index recorded highest value in bream (4.45) and perch (0.70), respectively (see Table 1). In perch and bream, the diversity parameters were very similar, while in roach the species diversity highly differed. After excluding the ectoparasites in calculations for roach, the Evenness, Simpson and Berger-Parker indices became very similar between Lake Tollense $(0.51,2.39,0.60)$ and Lake Hohen Sprenz (0.57, 2.11, 0.54), respectively, with the Shannon-Wiener index for the endohelminths remaining more different (1.18 vs 0.79). Lake Malchin still showed different diversity parameters compared with the other two lakes (lower values of Shannon-Wiener Index (0.19), Eveness (0.14) and Simpson Index (1.08) and higher value for Berger-Parker dominance (0.96).

To compare the results fromLake Tollense with Lake Malchin and Lake Hohen Sprenz, two other freshwater lakes in the region, the raw data from Pikalov [18] were analysed and calculated for parasitological terms as given in Tables 2 and 3 .

\section{Statistical Analysis}

A multivariate statistical analysis, Non-metric multidimensional scaling (NMDS) graph was performed in order to distinguish the habitats based on the parasite communities of the fish. Perch and bream showed separation of two habitats, Lake Tollense and Lake Malchin, based on their parasite communities. There is a clear separation of Lake Tollense and Lake Malchin based on perch parasite composition, while in bream, a few fish showed intermixing in both lakes (Fig. 1). ANOSIM results also supported this separation, with the values higher in perch $(R=0.73, p \leq 0.001)$ compared to bream $(R=0.45, p \leq 0.001)$.

In roach, separation was most distinct between Lake Tollense and Lake Hohen Sprenz, with lowest number of 
Table 2 Parasite fauna of perch and bream from Lake Malchin (changed after Pikalov [18])

\begin{tabular}{|c|c|c|c|c|c|c|}
\hline \multirow{3}{*}{$\begin{array}{l}\text { Parasite species } \\
\mathrm{N}\end{array}$} & \multicolumn{3}{|c|}{ Perca fluviatilis } & \multicolumn{3}{|c|}{ Abramis brama } \\
\hline & \multicolumn{3}{|l|}{35} & \multicolumn{3}{|l|}{35} \\
\hline & $\mathrm{P}(\%)$ & $\mathrm{mI}(\mathrm{I})$ & $\mathrm{mA}$ & $\mathrm{P}(\%)$ & $\mathrm{mI}(\mathrm{I})$ & $\mathrm{mA}$ \\
\hline \multicolumn{7}{|l|}{ Digenea } \\
\hline Azygia lucii & 8.57 & $1.33(1-2)$ & 0.11 & - & - & - \\
\hline Bunodera luciopercae & 71.43 & $4.12(1-19)$ & 2.94 & - & - & - \\
\hline Diplostomum baeri & 48.57 & $5.71(1-27)$ & 2.77 & - & - & - \\
\hline D. spathacaeum & - & - & - & 37.14 & $5.08(1-199)$ & 1.89 \\
\hline Ichthyocotylurus variegatus & 94.29 & $16.12(1-80)$ & 15.20 & - & - & - \\
\hline I. platycephalus & - & - & - & 80.00 & $8.07(1-41)$ & 6.46 \\
\hline Sphaerostoma bramae & - & - & - & 8.57 & $52.33(4-144)$ & 4.49 \\
\hline Posthodiplostomum brevicaudatum & 31.43 & $3.82(1-15)$ & 1.20 & - & - & - \\
\hline P. cuticula & - & - & - & 17.14 & $1.50(1-3)$ & 0.26 \\
\hline Tylodelphys clavata & 80.00 & $62.71(2-437)$ & 50.17 & 45.71 & $13.69(1-60)$ & 6.26 \\
\hline T. podicipina & 2.86 & $1.00(1)$ & 0.02 & - & - & - \\
\hline \multicolumn{7}{|l|}{ Cestoda } \\
\hline Caryophyllaeus laticeps & - & - & - & 8.57 & $1.00(1)$ & 0.09 \\
\hline Ligula intestinalis & - & - & - & 2.86 & $1.00(1)$ & 0.03 \\
\hline Paradilepis scolecina & - & - & - & 51.43 & $4.00(1-20)$ & 2.06 \\
\hline Proteocephalus percae & 2.86 & $1.00(2)$ & 0.06 & - & - & - \\
\hline Triaenophorus nodulosus & 68.57 & $3.17(1-11)$ & 2.17 & - & - & - \\
\hline \multicolumn{7}{|l|}{ Monogenea } \\
\hline Ancyrocephalus percae & 17.14 & $1.33(1-3)$ & 0.23 & - & - & - \\
\hline Diplozoan paradoxum & - & - & - & 14.29 & $1.60(1-3)$ & 0.23 \\
\hline \multicolumn{7}{|l|}{ Acanthocephala } \\
\hline Acanthocephalus lucii & 20.00 & $1.70(1-4)$ & 0.34 & - & - & - \\
\hline \multicolumn{7}{|l|}{ Nematoda } \\
\hline Camallanus spp. & 62.86 & $4.23(1-12)$ & 2.66 & - & - & - \\
\hline Contracaecum rudolphii & - & - & - & 88.57 & $15.23(1-65)$ & 13.49 \\
\hline Philometra ovata & - & - & - & 11.43 & $3.25(1-9)$ & 0.37 \\
\hline \multicolumn{7}{|l|}{ Crustacea } \\
\hline Argulus foliaceus & 5.71 & $1.00(1)$ & 0.06 & 14.29 & $1.20(1-2)$ & 0.17 \\
\hline Ergasilus sieboldi & 5.71 & $1.00(1)$ & 0.06 & 77.14 & $3.89(1-12)$ & 3.00 \\
\hline \multicolumn{7}{|l|}{ Ecological parameters } \\
\hline Richness & 14 & & & 13 & & \\
\hline Shannon Index $(\mathrm{H})$ & 1.19 & & & 1.86 & & \\
\hline Evenness (E) & 0.45 & & & 0.73 & & \\
\hline Simpson Index (D) & 2.19 & & & 5.01 & & \\
\hline Berger-Parker (BP) & 0.64 & & & 0.35 & & \\
\hline
\end{tabular}

I, intensity; MA, mean abundance; MI, mean intensity; N, number of examined fishes; P, prevalence fishes mixing between these lakes (Fig. 1). There are more fishes overlapping between Lake Malchin and Lake Hohen Sprenz (Fig. 1). This is further supported by the value of ANOSIM (Global $R=0.57, p \leq 0.001$ ) between the lakes. The highest value was observed between Lake Tollense and Lake Hohen Sprenz $(R=0.75, p \leq 0.001)$ while the lowest was between Lake Tollense and Lake Malchin $(R=0.43, p \leq 0.001)$.

\section{SIMPER Analysis}

SIMPER analysis was performed to identify the parasite species that were contributing most to the observed dissimilarity between the lakes for each fish species. For perch, a general dissimilarity of the parasite community of Lake Tollense and Lake Malchin is evident as both habitats create separated clusters (Fig. 1A). In perch, B. luciopercae and Ichthyocotyluris variegatus (Creplin, 1825) contributed the 
Table 3 Parasites fauna of Roach in Lake Malchin and Lake Hohen Sprenz (changed after Pikalov [18])

\begin{tabular}{|c|c|c|c|c|c|c|}
\hline \multirow{3}{*}{$\begin{array}{l}\text { Parasite species } \\
\mathrm{N}\end{array}$} & \multicolumn{3}{|c|}{ Lake Malchin } & \multicolumn{3}{|c|}{ Lake Hohen Sprenz } \\
\hline & \multicolumn{3}{|l|}{35} & \multicolumn{3}{|l|}{35} \\
\hline & $\mathrm{P}(\%)$ & $\mathrm{mI}(\mathrm{I})$ & $\mathrm{mA}$ & $\mathrm{P}(\%)$ & $\mathrm{mI}(\mathrm{I})$ & $\mathrm{mA}$ \\
\hline \multicolumn{7}{|l|}{ Digenea } \\
\hline Diplostomum spathacaeum & 48.57 & $5.59(1-18)$ & 2.71 & 37.14 & $1.77(1-6)$ & 0.66 \\
\hline Posthodiplostomum cuticula & 57.14 & $7.0(1-62)$ & 4.00 & 5.71 & $1.00(1)$ & 0.06 \\
\hline Tylodelphys clavata & 97.14 & $117.65(1-611)$ & 114.29 & 97.14 & $13.21(2-67)$ & 12.83 \\
\hline \multicolumn{7}{|l|}{ Cestoda } \\
\hline Paradilepis scolecina & 45.71 & $3.88(1-14)$ & 1.77 & 91.43 & $11.28(1-30)$ & 10.31 \\
\hline \multicolumn{7}{|l|}{ Monogenea } \\
\hline Dactylogyrus sphyrna & 8.57 & $3.67(1-5)$ & 0.31 & - & - & - \\
\hline Paradiplozoan homoin & 28.57 & $2.10(1-9)$ & 0.60 & 48.57 & $3.06(1-18)$ & 1.49 \\
\hline \multicolumn{7}{|l|}{ Nematoda } \\
\hline Contracaecum rudolphii & - & - & - & 8.57 & $1.00(1)$ & 0.09 \\
\hline Philometra ovata & 11.43 & $1.25(1-2)$ & 0.14 & - & - & - \\
\hline \multicolumn{7}{|l|}{ Crustacea } \\
\hline Argulus foliaceus & 5.71 & $1.00(1)$ & 0.06 & - & - & - \\
\hline Ergasilus sieboldi & 8.57 & $1.67(1-3)$ & 0.14 & - & - & - \\
\hline \multicolumn{7}{|l|}{ Ecological parameters } \\
\hline Richness & 9 & & & 6 & & \\
\hline Shannon Index $(\mathrm{H})$ & 0.39 & & & 0.99 & & \\
\hline Evenness (E) & 0.18 & & & 0.55 & & \\
\hline Simpson Index (D) & 1.18 & & & 2.36 & & \\
\hline Berger-Parker (BP) & 0.92 & & & 0.50 & & \\
\hline
\end{tabular}

I, intensity; MA, mean abundance; MI, mean intensity; N, number of examined fishes; P, prevalence most to the dissimilarity between Lake Tollense and Lake Malchin (Contribution overall $>50 \%$ ).

In bream, the dissimilarity of the parasite community from Lake Tollense and Lake Malchin was present, but not as prominent compared with perch. Contracaecum rudolphii, D. spathacaeum, Opecoelidae sp. and Ichthyocotylurus platycephalus (Creplin, 1825) were the most contributing parasite taxa to the dissimilarity between both lakes.

For roach, a certain grouping can be observed but is not as pronounced than in the other two fish species, as some fish are mixing. Comparing Lake Tollense and Lake Malchin roach, $T$. clavata and D. sphyrna contributed most to the dissimilarity. Same was evident for comparing Lake Tollense and Lake Malchin. Between Lake Malchin and Lake Hohen Sprenz, only T. clavata contributed almost $50 \%$ to their dissimilarity.

\section{Discussion}

\section{Parasite Fauna of Lake Tollense}

This study provides the first survey of the parasite community of three freshwater fish species, P. fluviatilis, A. brama and $R$. rutilus from Lake Tollense, northern Germany. The parasite fauna of Lake Tollense mostly consisted of autogenic species. Altogether, 32 parasite species were recorded, of which 24 species complete the entire life cycle in one ecosystem type (autogenic), while eight species had an allogenic life cycle. Of these allogenic species, seven were mature in fish-eating birds, whereas one digenean species, Gorgoderina lufengensis Gao and Zhang, 2014, uses frog as final host. In perch, the taxa B. luciopercae, D. baeri, T. clavata and Camallanus spp. were reported as core species, while monogeneans, acanthocephalans and crustaceans were classified as rare species (according to [27]). Two parasite taxa, D. spathacaeum and C. rudolphii, were considered as core species for bream. In roach, the core species were $A$. limacoides, $D$. spathacaeum, $T$. clavata and $D$. sphyrna.

This study provides a new locality record of Rhipidocotyle campanula (Dujardin, 1845) isolated from P. fluviatilis. This parasite species has been reported in P. fluviatilis from other countries such as Finland and Russia [10, 29]. A new host (A. brama) and locality record is described for G. lufengensis. This parasite taxon was first described from frog, Paa yunnanensis from China [30]. Same is true for Lissorchis kritskyi Barnhart \& Powell, 1979 and Prosorhynchoides borealis Bartoli, Gibson \& Bray, 2006 (in $R$. rutilus). Lissorchis kritskyi was first described from river carpsucker, Carpiodes carpio (Rafinesque, 1820) from USA 


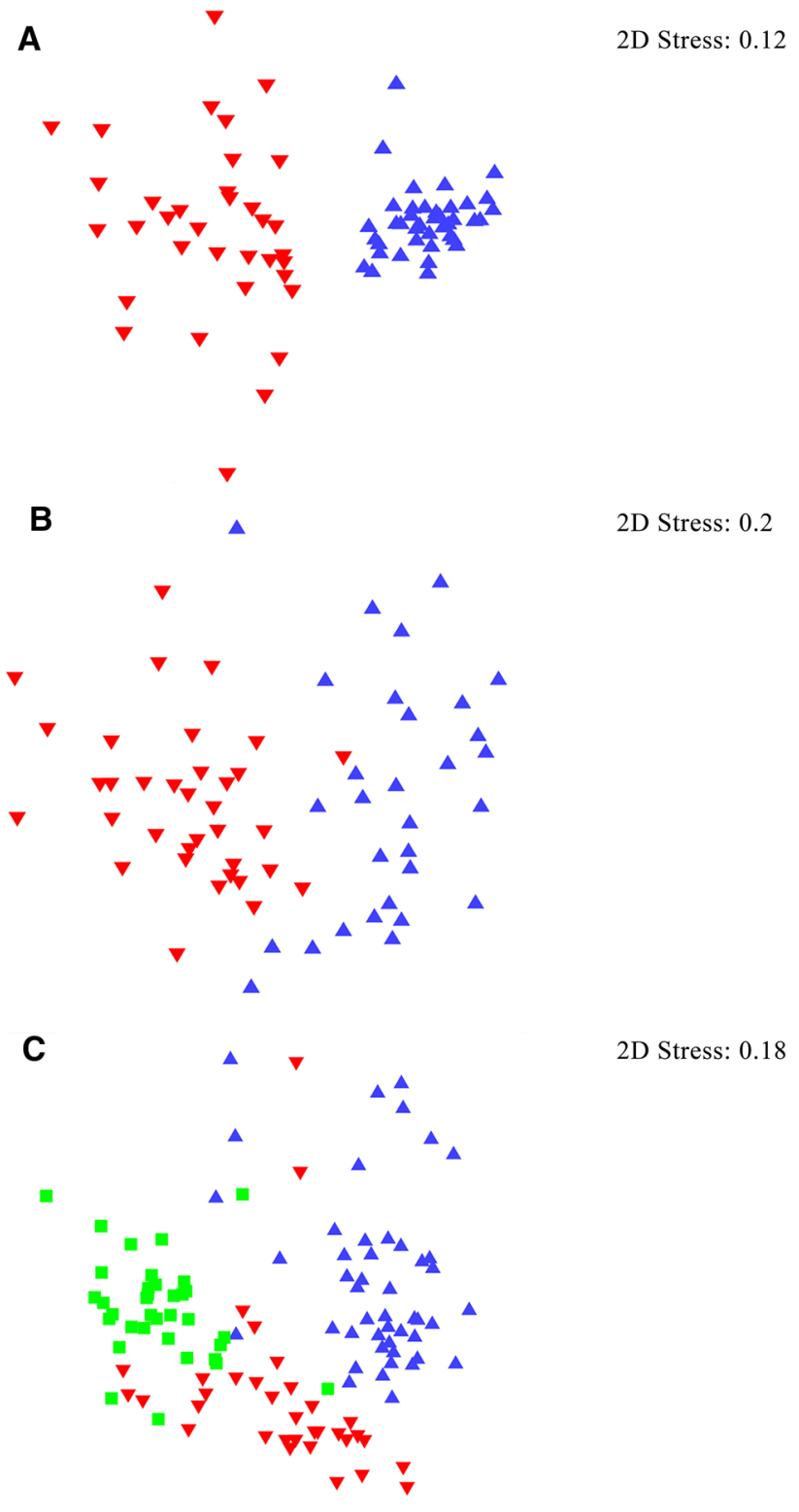

Fig. 1 Non-metric multidimensional scaling (NMDS) plot showing separation of lakes based on the parasite communities of perch (A), bream $(\mathbf{B})$ and roach $(\mathbf{C})$ from different lakes from MecklenburgWestern Pomerania, northern Germany by using Bray-Curtis similarity index (Symbols: Red triangle: Lake Malchin; Blue inverted triangle: Lake Tollense; Lime square: Lake Hohen Sprenz). For the purpose of statistical analysis, a single specimen of roach (Lake Malchin) was excluded due to presence of one individual parasite taxon (colour figure online)

[31], whereas $P$. borealis have been reported from angler fish, Lophius piscatorius (L.) from Iceland [32].

Similar to an earlier report by [33-36], digenean $D$. baeri inhabited perch, while only $D$. spathacaeum was identified in bream and roach. Similar findings have also been observed in previous studies in Germany. Moreover, D. baeri has also been reported from the Baltic Sea also in
Mecklenburg Western-Pomerania in Oncorhynchus mykiss Walbaum, 1792 [37]. It is important to note that Unger et al. [38] studied the parasite fauna of $O$. mykiss and Salvelinus alpinus (L.) from a nearby aquaculture farm which uses the surface water of Lake Tollense. These authors reported only $D$. spathacaeum in the examined hosts, but not $D$. baeri. The absence of D. baeri in cyprinid hosts may be due to their resistance against this digenean taxon or could be related with differences in the biology and ecology of the first and second intermediate hosts (snails and fish, respectively).

\section{Comparison of the Parasite Fauna Between Water Bodies}

Pikalov [18] investigated perch and bream from Lake Malchin and results revealed that these fish species have an almost similar composition of the parasite taxa compared with Lake Tollense, only exhibiting differences in their prevalence and abundance. In perch, the core species and generalist parasites B. lucioperca, T. clavata or Camallanus spp. were found in both habitats. In bream, the most common core and generalist parasite taxon in both lakes, Lake Tollense and Lake Malchin, was C. rudolphii.

In perch, prevalence and mean intensity of I. variegatus was much higher in Lake Malchin compared with Lake Tollense. Similarly, I. platycephalus was recorded from bream in Lake Malchin, but has not been found in Lake Tollense. The first intermediate host for both of these digenean species is a snail, Valvata piscinalis (Müller, 1774) [39]. The high abundance of Ichthyocotylurus spp. in Lake Malchin may be a result of the difference in abundance and seasonal distribution of snails as intermediate hosts in the lakes. Adverse climatic conditions, as it was shown by Mouthon and Daufresne [40] lead to a progressive decline and disappearance of the snail, V. piscinalis, in Saône River in France was related to higher water temperatures and a heatwave. In 2018, temperatures were exceptionally high in MecklenburgWestern Pomerania, and this can be a reason for the observed low prevalence or absence of this digenean species in hosts inhabiting Lake Tollense. However, we have also examined perch $(n=21)$ in the following year from Lake Tollense and there was only a marginal increase in the prevalence of $I$. variegatus. Besides the temperature, there could be some other factors such as habitat characteristics. Jokela and Lively [41] showed that the prevalence of the larval trematode Microphallus sp. was significantly higher in shallow water habitats than in deep water. This indicates that habitat characteristics have a significant influence on the occurrence of digenean parasites. Lake Malchin is a shallow lake (average depth: $2.5 \mathrm{~m}$ ). Therefore, we suggest that the combination of the factors temperature, lake characteristics, biological interactions, physical parameters and differences in distribution of the final and/or intermediate host were responsible for the 
observed variation in the occurrence and abundance of Ichthyocotylurus spp. between these two freshwater habitats.

For roach, the parasite fauna showed several differences in their prevalence and intensity between the studied lakes. In roach, only $D$. spathaceum, $T$. clavata, $P$. homoion and $P$. scolecina were constantly found in all lakes, but with differences in their occurrence and abundance. Aspidogaster limacoides was exclusively detected in Lake Tollense, but absent in both other habitats. Lake Tollense belongs to the Müritz freshwater system, an extensive natural lake and river system which represents an invasive species, the zebra mussel, Dreissena polymorpha, since the nineteenth century. The zebra mussel is a known definitive host for A. limacoides (see [42]). A study conducted by Prejs et al. [43] revealed that only roach with sizes of $16 \mathrm{~cm}$ and above feed on the zebra mussel (D. polymorpha). However, the average host size was comparatively higher in roach of Lake Tollense (standard length: about $21 \mathrm{~cm}$ ) compared with Lake Malchin and Lake Hohen Sprenz (standard length: approximately $13 \mathrm{~cm}$ ). On the other hand, Lake Hohen Sprenz is an isolated water body limiting species invasion and possibly also the presence of $A$. limacoides. Lake Malchin is connected to Lake Kummerow by the Peene, which drains into the Baltic Sea. It should also be kept in mind that $A$. limacoides does not show seasonal patterns as it was found throughout all seasons from Lake Tollense. Therefore, it can be concluded that the host size and habitat isolation were strong determinants for the presence or absence of A. limacoides in the sampled roach from different lakes.

\section{Diversity Parameters}

It is notable that despite the differences in the lakes' morphology and physico-chemical characteristics (isolation, topographical features and water quality), seasonality (years and seasons) and host attributes (host size and weight), parasite diversity parameters did not differ significantly between perch and bream.

Unlike perch and bream, roach showed variation in the diversity indices at the three localities. The most diverse parasite community was observed in Lake Tollense followed by Lake Malchin and the more isolated Lake Hohen Sprenz. This can be explained by the fact that Lake Tollense (17.9 $\mathrm{km}^{2}$ ) has the largest area of all studied lakes and belongs to the second largest river and lake system in Germany, the Müritz. Previous studies support our results regarding the lake size and the number of parasite species, for instance, Kennedy [44] found significant a correlation between species richness and lake size in brown trout (Salmo trutta L.), but not in Arctic charr, S. alpinus [45]. Our finding showed a positive association between the lake size and the species richness in roach.
The highest Shannon Wiener Index was detected from Lake Tollense followed by Lake Hohen Sprenz and Lake Malchin. Despite of having a smaller area, Lake Hohen Sprenz showed a higher Shannon index than Lake Malchin and the average host size was almost similar in both habitats. This suggests that the Shannon diversity is not always positively associated with the habitat size as well as host size. Similarly, a higher evenness was seen in Lake Hohen Sprenz compared with Lake Malchin. Previously, Salzmann et al. [15] found lower values for both these indices (Shannon index and evenness) in Lake Dörpfeld and stated that it was related with a small surface area and lack of fish stocking. However, this study does not support the explanation that low diversity and evenness in lakes refers to a small surface area as given by Salzmann et al. [15]. However, Salzmann et al. [15] studied artificial and anthropogenic strongly influenced freshwater systems in North-west Germany while the herewith sampled lakes are of ice age origin and surrounded by more pristine environments. Another possible reason for the observed differences in the diversity indices between these three lakes could be associated with their different trophic status of water bodies, e.g. Lake Tollense is a less disturbed habitat and thus, has a higher diversity while both other lakes are much more disturbed and hence, have low parasite species diversity. We could demonstrate that the differences of the diversity values for roach are mainly driven by the ectoparasites (three species in Lake Tollense, two species in Lake Malchin with low abundance and one species in Lake Hohen Sprenz).

\section{Statistical Analysis}

The parasite composition of perch, bream and roach was visualised by using NMDS, which showed distinct separation of the lakes with some minor overlapping depending on the fish species. All three fish species revealed separation of the three habitats. This was further supported by the result of ANOSIM which showed that there was a highly significant variation between lakes based on the parasite communities of studied fish species. This supports the notion by Salzmann et al. [15] that it is possible to distinguish freshwater ecosystems based on the parasite fauna of roach. However, identification of the concise reasons is more difficult and also requires parasitological analyses of other freshwater species.

\section{Conclusion}

It could be shown that based on the multivariate statistical analysis, NMDS composition of the parasite fauna of three sampled fish species differed between the studied lakes and therefore can be used to differentiate and characterise these natural freshwater habitats in Mecklenburg-Western 
Pomerania. Despite distinctly different trophic statuses of the three lakes, other differences in their topographical features and sampling time (between years and in seasons) and host attributes (e.g. host size) contributed to this result. Moreover, the diversity parameters were almost similar in perch and bream between two lakes, Lake Tollense and Lake Malchin, but not in roach where both diversity indices as well as the NMDS revealed a clear separation of habitats by this host. This suggests that in more natural, less influenced freshwater habitats the combination of two methods, in our case the diversity and NMDS, were required to evaluate the observed differences. The application of biological indicators must be strongly associated with concise differences in habitats (see [14]) if fish parasites can be used as relevant biological indicators for freshwater ecosystems in future. Further studies should focus on the investigation of the best suitable freshwater fish species for characterising distinct ecosystems and habitats and thus generating evaluable and comparable data.

Funding Open Access funding enabled and organized by Projekt DEAL. The present study was funded by the European Fisheries Fund and the Ministry of Agriculture and Environment, Mecklenburg-Western Pomerania as a part of the Project Hygiene management and health concept for surface water-dependent partial circulation systems in M.V. (MV-II. 12-LM-03). Grant No. 64160035.

Availability of Data and Material All data published within this text.

Code Availability Not applicable.

\section{Declarations}

Conflict of Interest The authors declare that they have no conflict of interest.

Ethical Approval Fishes were captured by local fishermen according to the international, national and/or institutional guidelines. Fish species is not listed in CITES or CMS and listed under Least Concern in IUCN Red List Status.

Human and animal rights Additional declarations for articles in life science journals that report the results of studiesinvolving humans and/ or animals.

Consent to Participate Not applicable.

Consent for Publication Not applicable.

Open Access This article is licensed under a Creative Commons Attribution 4.0 International License, which permits use, sharing, adaptation, distribution and reproduction in any medium or format, as long as you give appropriate credit to the original author(s) and the source, provide a link to the Creative Commons licence, and indicate if changes were made. The images or other third party material in this article are included in the article's Creative Commons licence, unless indicated otherwise in a credit line to the material. If material is not included in the article's Creative Commons licence and your intended use is not permitted by statutory regulation or exceeds the permitted use, you will need to obtain permission directly from the copyright holder. To view a copy of this licence, visit http://creativecommons.org/licenses/by/4.0/.

\section{References}

1. Ministry of Agriculture and the Environment. MecklenburgVorpommern-best of northern Germany. https://www.gover nment-mv.de/The-Ministries/Ministry-of-Agriculture-and-Envir onment/. Accessed 22 Feb 2021

2. Nixdorf B, Hemm M, Hoffmann A, Richter P (1994) Documentation of the condition and development of the most important lakes in Germany: Part 2 Mecklenburg-Western Pomerania, p. 370 .

3. Lappalainen A, Rask M, Koponen H, Vesala S (2001) Relative abundance, diet and growth of perch (Perca fluviatilis) and roach (Rutilus rutilus) at Tvärmine, northern Baltic Sea, in 1975 and 1997: responses to eutrophication? Boreal Environ Res 6:107-118

4. Hjelm J, Persson L, Christensen B (2000) Growth, morphological variation and ontogenetic niche shifts in perch (Perca fluviatilis) in relation to resource availability. Oecologia 122:190-199. https:// doi.org/10.1007/PL00008846

5. Froese R, Pauly D (2019) FishBase. World Wide Web electronic publication. www.fishbase.org. Accessed 12/2019

6. Cowx IG (1983) The biology of bream, Abramis brama (L), and its natural hybrid with roach, Rutilus rutilus $(\mathrm{L})$, in the River Exe. J Fish Biol 22(6):631-646. https://doi.org/10.1111/j.1095-8649. 1983.tb04223.x

7. Hoogenboezem W (2000) On the feeding biology of bream (Abramis brama). Neth J Zool 50(2):225-232. https://doi.org/10. 1164/156854200X00090

8. Persson L (1983) Food consumption and the significance of detritus and algae to intraspecific competition in roach Rutilus rutilus in a shallow eutrophic lake. Oikos 41(1):118-125. https://doi.org/ $10.2307 / 3544353$

9. Mehner T, Diekmann M, Brämick U, Lemcke R (2005) Composition of fish communities in German lakes as related to lake morphology, trophic state, shore structure and human-use intensity. Freshw Biol 50(1):70-85. https://doi.org/10.1111/j.1365-2427. 2004.01294.x

10. Valtonen ET, Holmes JC, Koskivaara M (1997) Eutrophication, pollution and fragmentation: effects on the parasite communities in roach and perch in four lakes in Central Finland. Can J Fish Aquat Sci 54(3):572-585. https://doi.org/10.1139/f96-306

11. Khan RA, Barker DE, Williams-Ryan K, Hooper RG (1994) Influence of crude oil and pulp and paper mill effluent on mixed infections of Trichodina cottidarium and T. saintjohnsi (Ciliophora) parasitizing Myxocephalus octodecemspinosus and M. scorpius. Can J Zool 72(2):247-251. https://doi.org/10.1139/z94-033

12. Palm HW, Dobberstein RC (1999) Occurrence of trichodinid ciliates (Peritricha: Urceolariidae) in the Kiel Fjord, Baltic Sea, and its possible use as a biological indicator. Parasitol Res 85(8):726732. https://doi.org/10.1007/s004360050622

13. Galli P, Crosa G, Mariniello L, Ortis M, D'amelio S (2001) Water quality as a determinant of the composition of fish parasite communities. Hydrobiologia 452(1):173-179. https://doi.org/10. 1023/A:1011958422446

14. Palm HW (2011) Fish parasites as biological indicators in a changing world. Can we monitor environmental impact and climate change? In: Mehlhorn $\mathrm{H}$ (ed) Progress in parasitology. Parasitology research monographs, vol 2. Springer, Berlin, Heidelberg. https://doi.org/10.1007/978-3-642-21396-0_12 
15. Salzmann A, Grabowski Y, Pikalov E, Wittsiepe J, Palm HW (2013) Parasite community and heavy metal contents of roach (Rutilus rutilus L.) from different freshwater habitats in North Rhine-Westphalia, Germany. Bull Fish Biol 14(1/2):43-59

16. Palm HW, Klimpel S, Bucher C (1999) Checklist of metazoan fish parasites of German coastal waters. Bericht aus dem Institut für Meereskunde an der Christian-Albrecht-Universität Kiel, vol 307, pp 1-148

17. Unger $P$ (2017) Parasite communities and interactions with commercially important fish species in the western Baltic Sea: parasitengemeinschaften und deren interaktionen mit wirtschaftlich bedeutenden fischarten in der westlichen Ostsee. Dissertation, University of Rostock, pp 1-152.

18. Pikalov E (2017) Fischparasiten in Mecklenburg-Vorpommern und nordeuropäischen Süßgewässern. Dissertation, University of Rostock, pp 1-411.

19. Palm HW, Bray RA (2014) Marine fish parasitology in Hawaii. Westarp

20. Palm HW (2004) The Trypanorhyncha Diesing, 1863. PKSPL-IPB

21. Klimpel S, Kuhn T, Münster J, Dörge DD, Klapper R, Kochmann J (2019) Parasites of marine fish and cephalopods. Springer International Publishing. https://doi.org/10.1007/978-3-030-16220-7

22. Suthar J, Sarah A, Bray RA, Theisen S, Palm HW (2021) Redescription of Aspidogaster limacoides (Aspidogastrea: Aspidogastridae) from freshwater fishes of northern Germany. Parasitol Res. https://doi.org/10.1007/s00436-021-07253-1

23. Palm HW, Waeschenbach A, Olson PD, Littlewood DTJ (2009) Molecular phylogeny and evolution of the Trypanorhyncha (Platyhelminthes: Cestoda). Mol Phylogenet Evol 52(2):351-367. https://doi.org/10.1016/j.ympev.2009.01.019

24. Blasco-Costa I, Faltýnková A, Georgieva S, Skírnisson K, Scholz T, Kostadinova A (2014) Fish pathogens near the Arctic Circle: molecular, morphological and ecological evidence for unexpected diversity of Diplostomum (Digenea: Diplostomidae) in Iceland. Int J Parasitol 44(10):703-715. https://doi.org/10.1016/j.ijpara.2014. 04.009

25. Santos MJ, Castro R, Cavaleiro F, Rangel L, Palm HW (2017) Comparison of anisakid infection levels between two species of Atlantic mackerel (Scomber colias and S. scombrus) off the Atlantic Portuguese coast. Sci Mar 81(2):179-185. https://doi.org/10. 3989/scimar.04552.26A

26. Bush AO, Lafferty KD, Lotz JM, Shostak AW (1997) Parasitology meets ecology on its own terms: Margolis et al. revisited. J Parasitol 83(4):575-583. https://doi.org/10.2307/3284227

27. Holmes JC (1991) Spatial scale and important species in the analysis of communities of parasites, vol 28. Second International School: Parasite-Host Environment, Sofia, p 14

28. Unger P, Neubert K, Palm HW (2018) Metazoan parasite fauna of migrating common garfish, Belone belone (L.), in the Baltic Sea. Acta Parasitol 63(1):99-105. https://doi.org/10.1515/ ap-2018-0011

29. Dugarov ZN, Burdukovskaya TG, Batueva MD, Baldanova DR, Sondueva LD, Zhepkholova OB, Mazur OE (2018) Changes in the species composition of parasites in European Perch, Perca fluviatilis, in Lake Gusinoye (Lake Baikal Basin) during depression and subsequent recovery of host abundance. Russ J Ecol 49(3):248-252. https://doi.org/10.1134/S1067413618030037

30. Gao P, Zhang L (2014) A new species of the genus Gorgoderina (Digenea: Gorgoderidae) in the Paa yunnanensis. J Chongqing Norm Univ 31(6):34-38

31. Barnhart MC, Powell EC (1979) Lissorchis kritskyi sp. N. (Digenea: Lissorchiidae) from the river carpsucker, Carpiodes carpio (Rafinesque). Proc Helminthol Soc Wash 46(1):47-51
32. Eydal M, Freeman MA, Kristmundsson A, Bambir SH, Jonsson PM, Helgason S (2013) Prosorhynchoides borealis Bartoli, Gibson \& Bray, 2006 (Digenea: Bucephalidae) cercariae from Abra prismatica (Mollusca: Bivalvia) in Icelandic waters. J Helminthol 87(1):34-41. https://doi.org/10.1017/S0022149X11000782

33. Höglund J, Thulin J (1982) Identification of Diplostomum spp. in the retina of perch Perca fluviatilis and the lens of roach Rutilus rutilus from the Baltic Sea-an experimental study. Syst Parasitol 21(1):1-19. https://doi.org/10.1007/BF00009910

34. Rückert S, Klimpel S, Palm HW (2007) Parasite fauna of bream Abramis brama and roach Rutilus rutilus from a man-made waterway and a freshwater habitat in northern Germany. Dis Aquat Org 74(3):225-233. https://doi.org/10.3354/dao074225

35. Behrmann-Godel J (2013) Parasite identification, succession and infection pathways in perch fry (Perca fluviatilis): new insights through a combined morphological and genetic approach. Parasitology 140(4):509-520. https://doi.org/10.1017/S003118201 2001989

36. Georgieva S, Soldánová M, Pérez-del-Olmo A, Dangel DR, Sitko J, Sures B, Kostadinova A (2013) Molecular prospecting for European Diplostomum (Digenea: Diplostomidae) reveals cryptic diversity. Int J Parasitol 43(1):57-72. https://doi.org/10.1016/j. ijpara.2012.10.019

37. Unger P, Palm HW (2017) Parasite risk of maricultured rainbow trout (Oncorhynchus mykiss Walbaum, 1792) in the Western Baltic Sea, Germany. Aquac Int 25(2):975-989

38. Unger P, Neitemeier-Duventester X, Baustian F, Suthar J, Kleinertz S, Palm HW (2021) Seasonality of salmonid parasites from flow-through aquaculture in northern Germany: emphasis on Diplostomum spp. metacercaria. Manuscript submitted for publication

39. Swennen C, Heessen HJL, Höcker AWM (1979) Occurence and biology of the trematodes cotylurus (ichthycotylurus) erraticus, C.(I.) variegatus and C.(I.) platycephalus (digenea: strigeidae) in the Netherlands. Neth J Sea Res 13(2):161-191. https://doi.org/ 10.1016/0077-7579(79)90001-2

40. Mouthon J, Daufresne M (2008) Population dynamics and life cycle of Pisidium amnicum (Müller) (Bivalvia: Sphaeriidae) and Valvata piscinalis (Müller) (Gastropoda: Prosobranchia) in the Saône river, a nine-year study. Ann Limnol Int J Limnol 44(4):241-251. https://doi.org/10.1051/limn:2008008

41. Jokela J, Lively CM (1995) Spatial variation in infection by digenetic trematodes in a population of freshwater snails (Potamopyrgus antipodarum). Oecologia 103(4):509-517. https://doi.org/10. 1007/BF00328690

42. Nagibina LF, Timofeeva TA (1971) The true hosts of Aspidogaster limacoides Diesing, 1834 (Trematoda: Aspidogastrea). Dokl Akad Nauk SSSR 200(3):742-744

43. Prejs A, Lewandowski K, Stańczykowska-Piotrowska A (1990) Size-selective predation by roach (Rutilus rutilus) on zebra mussel (Dreissena polymorpha): field studies. Oecologia 83(3):378-384. https://doi.org/10.1007/BF00317563

44. Kennedy CR (1978) An analysis of the metazoan parasitocoenoses of brown trout Salmo trutta from British lakes. J Fish Biol 13(2):255-263. https://doi.org/10.1111/j.1095-8649.1978. tb03433.x

45. Kennedy CR (1978) The parasite fauna of resident char Salvelinus alpinus from Arctic islands, with special reference to Bear Island. J Fish Biol 13(4):457-466. https://doi.org/10.1111/j.1095-8649. 1978.tb03455.x

Publisher's Note Springer Nature remains neutral with regard to jurisdictional claims in published maps and institutional affiliations. 